\title{
PENGARUH PUPUK ORGANIK DAN BATUAN FOSFAT ALAM PADA INCEPTISOL SEBAGAI MEDIA TANAM TERHADAP PERBANYAKAN MIKORIZA ARBUSKULA (MA) DENGAN BERBAGAI TANAMAN INANG
}

\section{The effect of Organic Fertilizer and Rock Phosphate on an Inceptisol as Planting Media for Arbuscular Mycorrhiza (AM) Multiplication with Various Host Plants}

\author{
Budi Prasetya*, Ikhya Ulum Ukhtansyah \\ Jurusan Tanah, Fakultas Pertanian, Universitas Brawijaya, Jl. Veteran no 1, Malang 65145 \\ *Penulis korespondensi: budiprasetya@ub.ac.id
}

\begin{abstract}
The distribution of very abundant AM in UB forest is very potential to be used as biological fertilizer. Biofertilizer production through the utilization of AM spores requires the multiplication of AM by using host plants namely maize (Zea mays L.), soybean (Glycine max (L) Merill) and tithonia (Tithonia diversifolia) and planting media consisting of soil added with cattle manure and rock phosphate. This study aimed to obtain the best host plants and growing media in producing the number of AM spores and AM colonies so that they can be used as AM biological fertilizer production. The study design used was a factorial randomized group design with host plants $(\mathrm{H})$ as the first factor and planting media $(\mathrm{M})$ as the second factor consisting of 18 treatments with 3 replications. The multiplication results showed that media with an M5 dose $\left(150 \mathrm{~kg} \mathrm{ha}^{-1}\right.$ rock phosphate $+5 \mathrm{tha}^{-1}$ cattle manure) was high in producing $\mathrm{AM}$ spores amounting to $324,67 \mathrm{AM} 100 \mathrm{~g}^{\text {soil }^{-1}}$ in maize and $61.11 \% \mathrm{AM}$ colonies in soybeans. Rock phosphate and cattle manure were sources of $P$ in the growing media and AM which was multiplied to carry out its activities in producing phosphatase enzymes to produce $\mathrm{P}$ available for plants. Maize and soybeans had stable growth, good rooting, fast plant growth and low root lignin content which made it easy for AM to make colonies.
\end{abstract}

Keywords: AM colonies, host plants, mycorrbiza, number of $A M$ spores, planting media

\section{Pendahuluan}

Keberadaan MA (Mikoriza Arbuskula) pada ekosistem pertanian sangat luas karena MA memiliki simbiosis mutualisme dengan akar tanaman dan dapat tumbuh dalam setiap jenis tanaman yang berperan sebagai inang diantaranya tanaman perkebunan, tanaman musiman dan tanaman tahunan. UB forest yang terletak di Desa Tawang Argo Kecamatan Karangploso memiliki bentuk penggunaan lahan agroforestri yang terdiri dari tanaman tahunan diantaranya pinus, mahoni, kopi dan tanaman musiman diantaranya kubis, cabai, jagung, ketela pohon sehingga mampu memainkan peran penting dalam pelestarian sumberdaya hutan salah satunya yaitu MA. Penelitian Musafa et al. (2015) menunjukkan eksplorasi MA di UB Forest pada penggunaan lahan pinus (11-15 tahun) + kopi (P3k) menghasilkan jumlah spora MA tertinggi sebesar 327 spora $100 \mathrm{~g} \operatorname{tanah}^{-1}$. Melihat sebaran MA yang sangat melimpah di UB forest ini sangat berpotensi apabila MA digunakan sebagai pupuk hayati karena MA memiliki dapat merubah morfologi akar tanaman sehingga mengakibatkan pembesaran sistem akar, dengan 


\section{Jurnal Tanah dan Sumberdaya Lahan Vol 7 No 1 : 109-119, 2020 e-ISSN:2549-9793, doi: 10.21776/ub.jts1.2020.007.1.14}

demikian luas permukaan akar untuk menyerap unsur hara P menjadi lebih besar.

Salah satu hal yang menyebabkan kurangnya pemanfaatan pupuk hayati MA di masyarakat khususnya petani di Indonesia adalah masih terbatasnya pengetahuan petani dalam memanfaatkan pupuk hayati MA. Petani memilih menggunakan pupuk kimia karena efektivitas dari pupuk kimia yang baik untuk pertumbuhan tanaman, namun pengggunaan pupuk kimia yang berlebihan dan melebihi batas penggunaan berdampak pada lingkungan dan produksi pertanian. Adanya pupuk hayati MA mampu menggantikan penggunaan dari pupuk kimia sehinggga lebih ramah lingkungan. Penggunaan pupuk hayati MA juga mampu memberikan kebutuhan unsur hara $\mathrm{P}$ untuk tanaman dengan meningkatkan serapan hara melalui hifa eksternal MA (Herryawan, 2012).

Pemanfaatan spora MA untuk memproduksi pupuk hayati perlu dilakukan perbanyakan dengan menggunakan tanaman inang dan media tanam sebagai media pertumbuhan antara tanaman inang dan MA. Pada umumnya kegiatan perbanyakan MA dapat dilakukan dengan cara kultur pot dimana MA yang telah diketahui genus dan keefektifannya diinokulasikan pada tanaman inang dan media tanam steril yang berada didalam pot pengamatan (Nurbaity dan Prafitiasari, 2010). Kriteria yang paling penting dalam menentukan tanaman inang yaitu memiliki interaksi yang baik dengan MA, memiliki sistem perakaran yang ekstensif dan tidak mengandung kadar lignin yang tinggi serta mampu tumbuh dalam kondisi ruang pertumbuhan seperti rumah kaca (Herryawan, 2012). Penelitian Tahat et al. (2008) menggunakan tanaman inang jagung, kedelai, kacang hijau dan gandum dalam kegiatan perbanyakan MA genus Glomus mosseae dan mampu menghasilkan rata-rata jumlah spora sebesar $111-167$ spora $10 \mathrm{~g}$ tanah $^{-1}$. Sedangkan Tithonia difersivolia memiliki beberapa fungsi dan yang terutama sebagai pupuk hijau. Media tanam sebagai media pertumbuhan tanaman inang dan MA harus memberikan kondisi yang baik seperti halnya kandungan unsur hara pada media tanam. Ketersediaan unsur hara pada media tanam mendukung pertumbuhan tanaman inang untuk proses fotosintesis. Pemberian pupuk kandang dan fosfat alam pada media tanam dapat meningkatkan ketersediaan sumber $\mathrm{P}$ dalam media tanam dan MA yang diinokulasikan selama proses perbanyakan dapat mengubah $\mathrm{P}$ pada pupuk kandang dan fosfat alam menjadi $\mathrm{P}$ tersedia dan siap untuk diserap tanaman inang.

Berdasarkan pada penjelasan diatas tanaman inang jagung (Zea mays L.), kedelai (Glycine max (L) Merill) dan tithonia (Tithonia diversifolia) serta media tanah yang ditambahkan dengan pupuk kandang dan fosfat alam dapat dijadikan sebagai pilihan yang tepat dan efisien sebagai media tanam untuk proses perbanyakan MA dan diharapkan mampu menghasilkan kuantitas dan kualitas spora MA yang baik sehingga dapat dimanfaatkan sebagai produksi pupuk hayati

\section{Bahan dan Metode}

\section{Tempat, waktu dan bahan penelitian}

Penelitian dilakukan dalam pot di rumah kaca Desa Sengkaling, Kab. Malang pada bulan MeiNovember 2018. Analisa tanah dan tanaman dilakukan di Laboratorium Biologi dan Laboratorium Kimia Jurusan Tanah Fakultas Pertanian Universitas Brawijaya Malang. Alat yang digunakan yaitu cetok, pot, plastik, timbangan, ayakan bertingkat, cawan petri, fial film, kaca preparat, sentrifuge, enlenmeyer, pipet, spektronik 21, $\mathrm{pH}$ meter, mesin pengocok, mikroskop. Bahan yang digunakan yaitu tanah Inceptisol, aquadest, larutan gula 60\%, FAA (Formalin Alcobol Asetat), KOH 10\%, $\mathrm{HCl} 2 \%$, trypan blue dalam laktofenol 0,05\%, fosfat alam, pupuk kandang sapi, tisu, benih jagung varietas talenta, benih kedelai varietas anjasmoro, pengekstrak Bray-1, asam nitrat, asam peklorat. Penelitian ini menggunakan Rancangan Acak Kelompok Faktorial, yang terdiri dari 18 perlakuan dengan 3 kali ulangan.

\section{Persiapan tanah}

Pengambilan tanah dilakukan di UB Forest pada rizhosfer tanaman kopi dan pinus untuk media tanam yang akan digunakan dalam kegiatan perbanyakan MA. Pengambilan tanah dilakukan secara komposit pada kedalaman $45 \mathrm{~cm}$ sebanyak $150 \mathrm{~kg}$.

\section{Isolasi dan identifikasi MA}

Isolasi MA dilakukan sebelum inokulasi terhadap akar tanaman inang dan jumlah spora 
yang diinokulasikan sebesar 20 spora MA perlakuan $^{-1}$. Metode isolasi MA menggunakan ayakan basah (wet sieving).

\section{Perbanyakan $\boldsymbol{M A}$}

Perbanyakan MA dilakukan dengan cara kultur pot menggunakan MA yang telah di isolasi sebelumnya sebanyak 20 spora perlakuan ${ }^{-1}$. Sebelum pelaksanaan perbanyakan MA, dilakukan persiapan media tanam, persiapan tanaman inang dan selanjutnya inokulasi.

\section{Persiapan Media Tanam}

Media tanam tanah, fosfat alam dan pupuk kandang diayak dengan ayakan $2 \mathrm{~mm}$. Selanjutnya disterilisasi dengan dipanaskan atau dikukus selama 2 jam hari ${ }^{-1}$ selama 3 hari berturut-turut dengan suhu $100^{\circ} \mathrm{C}$ agar media tanam steril dari mikroba fungi yang ada sebelumnya.

\section{Persiapan Tanaman Inang}

Tanaman inang yang digunakan adalah jagung (Zea mays L.), kedelai (Glycine max (L) Merill) dan tithonia (Tithonia diversifolia). Benih tanaman jagung dan kedelai disemai terlebih dahulu selama 5 hari sebelum inokulasi. Sedangkan untuk tanaman tithonia sebelum inokulasi ditanam terlebih dahulu selama 2 minggu dengan cara stek batang untuk menumbuhkan akarnya.

\section{Inokulasi $M A$}

Inokulasi MA dilakukan dengan cara langsung menuangkan spora MA pada akar tanaman inang yang telah diletakkan pada lubang tanam

\section{Pengamatan pertumbuhan tanaman inang}

Pengamatan pertumbuhan tanaman inang (Tinggi tanaman dan jumlah daun) dilakukan pada tiap 1 minggu sekali. Pengamatan tinggi tanaman dan jumlah daun dilakukan secara kuantitatif (perhitungan secara langsung). Pengamatan bobot kering tanaman dilakukan untuk mengetahui rasio akar tajuk pada masingmasing perlakuan. Tanaman inang yang telah dipanen selanjutnya ditimbang bobot awal masing- masing bagian tanaman. Setelah itu dimasukkan kedalam kertas amplop untuk dioven pada suhu $80^{\circ} \mathrm{C}$ selama 48 jam, setelah dioven selanjutnya ditimbang bobot keringnya.

\section{Pengamatan dan pengumpulan data}

Setelah dilakukan perbanyakan MA sesuai dengan perlakuan dan jadwal panen yang telah direncakan, kemudian dilakukan pengamatan di laboratorium pada parameter pengamatan meliputi jumlah spora MA, koloni MA, $\mathrm{pH}$ media tanam, P tersedia, Berat Kering tanaman serta kadar P di dalam jaringan tanaman (untuk menghitung banyaknya serapan P) pada 49 hst.

\section{Analisis data}

Data hasil pengamatan dianalisis keragamannya (ANOVA) menggunakan software Genstat 12th. Apabila variabel yang dianalisis berpengaruh nyata, maka dilanjutkan dengan uji Duncan's Multiple Range Test (DMRT) 5\% untuk mengetahui perbedaan antar perlakuan. Adanya hubungan antara kedua variabel dapat diketahui melalui uji korelasi. Apabila terdapat hubungan antar variabel dilakukan uji regresi untuk mengetahui seberapa besar hubungan antar variabel tersebut. Analisis korelasi dan regresi ini dilakukan menggunakan software Ms.Exel 2016.

\section{Hasil dan Pembahasan}

\section{Jumlah spora MA}

Terjadi interaksi antara tanaman inang dan media tanam terhadap jumlah spora MA (100 g tanah $\left.^{-1}\right)$. Interaksi yang terjadi antara tanaman inang dan media tanam menunjukkan tanaman inang jagung yang ditanam pada media tanam M5 menghasilkan jumlah spora MA tertinggi sebesar 324,7 spora. Pemberian pupuk kandang dan fosfat alam sebagai media tanam pada tanaman inang dalam kegiatan perbanyakan MA menghasilkan rata-rata jumlah spora MA tiap $100 \mathrm{~g} \mathrm{tanah}^{-1}$ sebesar 273,67 hingga 324,67 spora sejak pengaplikasian spora awal sebesar 20 spora MA. Hasil jumlah spora MA yang dihasilkan tersebut didukung oleh penelitian (Carrenho et al, 2002) yang menunjukkan pengaplikasian spora awal sebesar 30 spora dalam perbanyakan MA pada tanaman inang jagung, kacang tanah dan sorgum menghasilkan jumlah spora MA tiap $100 \mathrm{~g}$ tanah $^{-1}$ sebesar 436, 285, dan 597 spora MA (Tabel 1). Pemberian fosfat alam dengan dosis fosfat alam tertinggi sebesar 150 kg ha-1 mampu menghasilkan jumlah spora MA terbaik dalam perbanyakan MA ini, adanya MA 


\section{Jurnal Tanah dan Sumberdaya Lahan Vol 7 No 1 : 109-119, 2020 e-ISSN:2549-9793, doi: 10.21776/ub.jts1.2020.007.1.14}

mampu mengubah unsur hara $\mathrm{P}$ yang terkandung dalam fosfat alam yang sebelumnya tidak tersedia menjadi tersedia. Menurut Rosliani et al. (2009) fosfat alam sebagai bahan organik merupakan sumber energi bagi perkembangan mikroorganisme yaitu MA. Perkembangan MA yang baik dapat mendukung aktivitas MA dalam memproduksi enzim fosfatase sehingga dapat mengubah P-organik menjadi P-anorganik $\left(\mathrm{H}_{2} \mathrm{PO}_{4^{-}}\right.$dan $\left.\mathrm{HPO}_{4}{ }^{2-}\right)$ yang merupakan bentuk $\mathrm{P}$ tersedia untuk tanaman. Melalui proses fotosintesis tanaman akan menghasilkan karbohidrat untuk perkembangan MA. Jenis tanaman inang juga menjadi faktor penting dalam kegiatan perbanyakan MA. Tanaman jagung dan kedelai yang digunakan sebagai tanaman inang dalam perbanyakan MA ini mampu menghasilkan ratarata jumlah spora MA tertinggi apabila dibandingkan dengan tanaman tithonia. Jagung dan kedelai memiliki pertumbuhan yang stabil, perakaran yang baik, pertumbuhan tanaman yang cepat dan kandungan lignin pada akar yang rendah sehingga mudah untuk dikoloni oleh MA. Menurut (Tahat et al, 2008) jagung dan kedelai memiliki pertumbuhan yang cepat serta dapat tumbuh dalam setiap kondisi untuk memproduksi spora.

Tabel 1. Pengaruh tanaman inang dan media tanam terhadap jumlah spora Glomus sp.

\begin{tabular}{ccccccc}
\hline \multirow{2}{*}{ Perlakuan } & \multicolumn{7}{c}{ Jumlah Spora 100 $\mathbf{g}$ tanah $^{-1}$} \\
\cline { 2 - 7 } & M0 & M1 & M2 & M3 & M4 & M5 \\
\hline Jagung & $288,33 \mathrm{~b}$ & $300,67 \mathrm{~cd}$ & $320,00 \mathrm{fg}$ & $296,67 \mathrm{bc}$ & $320,00 \mathrm{fg}$ & $324,67 \mathrm{~g}$ \\
Kedelai & $286,00 \mathrm{~b}$ & $292,33 \mathrm{bc}$ & $311,33 \mathrm{def}$ & $297,33 \mathrm{bc}$ & $314,67 \mathrm{fg}$ & $312,67 \mathrm{efg}$ \\
Tithonia & $273,67 \mathrm{a}$ & $302,00 \mathrm{cde}$ & $290,33 \mathrm{bc}$ & $296,67 \mathrm{bc}$ & $314,33 \mathrm{fg}$ & $322,00 \mathrm{fg}$ \\
\hline
\end{tabular}

Keterangan : Angka yang diikuti huruf yang sama menunjukkan tidak berbeda nyata (DMRT 5\%). Media Tanam : M0 (tanah + kontrol), M1 (Tanah + pupuk kandang $\left.15 \mathrm{t} \mathrm{ha}^{-1}\right), \mathrm{M} 2\left(\right.$ Tanah + fosfat alam $\left.150 \mathrm{~kg} \mathrm{ha}^{-1}\right), \mathrm{M}^{2}$ (Tanah + pupuk kandang $15 \mathrm{t} \mathrm{ha}^{-1}+$ fosfat alam $\left.50 \mathrm{~kg} \mathrm{ha}^{-1}\right)$, M4 (Tanah + pupuk kandang $10 \mathrm{t} \mathrm{ha}^{-1}+$ fosfat alam $100 \mathrm{~kg} \mathrm{ha}^{-1}$ ), M5 (Tanah + pupuk kandang $5 \mathrm{t} \mathrm{ha}^{-1}+$ fosfat alam $150 \mathrm{~kg} \mathrm{ha}^{-1}$ ).

\section{Koloni MA}

Terjadi interaksi antara media tanam dan tanaman inang terhadap koloni MA. Interaksi antara tanaman inang dan media tanam menunjukkan tanaman inang kedelai yang ditanam pada media M5 menghasilkan koloni MA tertinggi sebesar 61,11\%. Pemberian pupuk kandang dan fosfat alam sebagai media tanam jagung, kedelai dan tithonia dalam kegiatan perbanyakan MA mampu menghasilkan jumlah spora MA yang berbeda pada masing-masing perlakuan (Tabel 2). Pemberian fosfat alam dengan dosis fosfat alam tertinggi sebesar 150 $\mathrm{kg} \mathrm{ha}^{-1}$ mampu menghasilkan koloni MA terbaik dalam kegiatan perbanyakan, adanya MA yang dihasilkan selama proses perbanyakan ini akan meningkatkan aktivitasnya dalam mengubah unsur hara P yang tidak tersedia pada fosfat alam menjadi tersedia sehingga nantinya akan diserap tanaman untuk pertumbuhannya.

Tabel 2. Pengaruh perlakuan terhadap koloni MA.

\begin{tabular}{cllllll}
\hline \multirow{2}{*}{ Perlakuan } & \multicolumn{7}{c}{ Koloni MA ( \% ) } \\
\cline { 2 - 7 } & \multicolumn{1}{c}{ M0 } & \multicolumn{1}{c}{ M1 } & M2 & M3 & M4 & \multicolumn{1}{c}{ M5 } \\
\hline Jagung & $38,89 \mathrm{ab}$ & $55,56 \mathrm{fg}$ & $58,89 \mathrm{fg}$ & $47,78 \mathrm{cde}$ & $57,78 \mathrm{fg}$ & $54,44 \mathrm{efg}$ \\
Kedelai & $34,45 \mathrm{a}$ & $44,44 \mathrm{bc}$ & $61,11 \mathrm{~g}$ & $43,33 \mathrm{bc}$ & $56,67 \mathrm{fg}$ & $61,11 \mathrm{~g}$ \\
Tithonia & $42,22 \mathrm{bc}$ & $45,56 \mathrm{bcd}$ & $53,34 \mathrm{ef}$ & $45,56 \mathrm{bcd}$ & $52,22 \mathrm{def}$ & $56,56 \mathrm{fg}$ \\
\hline
\end{tabular}

Keterangan : Angka yang diikuti huruf yang sama menunjukkan tidak berbeda nyata (DMRT 5\%). Media Tanam : M0 (tanah + kontrol), M1 (Tanah + pupuk kandang $\left.15 \mathrm{t} \mathrm{ha}^{-1}\right), \mathrm{M} 2\left(\right.$ Tanah + fosfat alam $\left.150 \mathrm{~kg} \mathrm{ha}^{-1}\right), \mathrm{M} 3$ (Tanah + pupuk kandang $15 \mathrm{t} \mathrm{ha}^{-1}+$ fosfat alam $\left.50 \mathrm{~kg} \mathrm{ha}^{-1}\right)$, M4 (Tanah + pupuk kandang $10 \mathrm{t} \mathrm{ha}^{-1}+$ fosfat alam $100 \mathrm{~kg} \mathrm{ha}^{-1}$ ), M5 (Tanah + pupuk kandang $5 \mathrm{t} \mathrm{ha}^{-1}+$ fosfat alam $150 \mathrm{~kg} \mathrm{ha}{ }^{-1}$. 


\section{Jurnal Tanah dan Sumberdaya Lahan Vol 7 No 1 : 109-119, 2020 e-ISSN:2549-9793, doi: 10.21776/ub.jts1.2020.007.1.14}

Menurut Hanafiah et al. (2009) prinsip kerja dari MA adalah mengkoloni sistem perakaran tanaman inang, memproduksi jalinan hifa secara intensif sehingga mampu meningkatkan kapasitas penyerapan unsur hara. Kestabilan pertumbuhan tanaman inang sangat dipertimbangkan dalam pentingnya produksi MA. Tanaman inang kedelai dan jagung menghasilkan nilai persentase koloni MA tertinggi apabila dibandingakan dengan tanaman tithonia. Pertumbuhan tanaman inang yang baik akan melakukan proses fotosintesis dengan baik sehingga hasil proses fotosintesis berupa karbohidrat dapat terpenuhi untuk perkembangan MA. Selain itu, perakaran yang ekstensif pada tanaman inang menjadi hal yang perlu dipertimbangkan dalam produksi MA karena perkembangan MA sangat bergantung pada akar tanaman inang.

\section{$P$ tersedia}

Terjadi interaksi antara tanaman inang dan media tanam terhadap nilai $\mathrm{P}$ tersedia. Pemberian pupuk kandang dan fosfat alam sebagai media tanam pada tanaman inang dalam kegiatan perbanyakan MA menghasilkan nilai $\mathrm{P}$ tersedia dari kategori sedang hingga sangat tinggi (Tabel 3). Perkembangan spora MA dapat diketahui melalui aktivitasnya dalam memineralisasi unsur $\mathrm{P}$ pada pupuk kandang dan fosfat alam yang sebelumnya tidak tersedia menjadi tersedia untuk tanaman. Pemberian fosfat alam dan pupuk kandang mampu meningkatkan sumber $\mathrm{P}$ dalam media tanam sehingga perkembangan MA melalui aktivitasnya dalam memineralisasi unsur $\mathrm{P}$ juga meningkat. Menurut Syibli et al (2013) P tersedia yang terdapat di media tanam dikarenakan aktivitas enzim yang dihasilkan MA yaitu enzim fosfatase pada daerah perakaran dapat memineralisasi unsur $\mathrm{P}$ organik yang tidak tersedia menjadi $\mathrm{P}$ anorganik yang tersedia untuk tanaman. Selain itu menurut Singh dan Reddy (2011) fosfatase yang diproduksi oleh MA memainkan peran utama dalam memineralisasi P organik dan melepaskan unsur hara $\mathrm{P}$ yang tersedia untuk tanaman..

Tabel 3. Pengaruh perlakuan terhadap P tersedia pada 49 HST.

\begin{tabular}{ccccccc}
\hline \multirow{2}{*}{ Perlakuan } & \multicolumn{5}{c}{ P Tersedia $\left(\mathrm{mg} \mathrm{kg}^{-1}\right)$} \\
\cline { 2 - 7 } & M0 & M1 & M2 & M3 & M4 & M5 \\
\hline Jagung & $14.45 \mathrm{ab}$ & $26.24 \mathrm{defg}$ & $29.14 \mathrm{fgh}$ & $23.56 \mathrm{cdef}$ & $25.80 \mathrm{cdefg}$ & $27.96 \mathrm{efgh}$ \\
Kedelai & $18.98 \mathrm{bcd}$ & $27.02 \mathrm{defg}$ & $35.60 \mathrm{hi}$ & $32.11 \mathrm{ghi}$ & $31.42 \mathrm{fghi}$ & $27.75 \mathrm{efgh}$ \\
Tithonia & $9.45 \mathrm{a}$ & $44.62 \mathrm{j}$ & $18.86 \mathrm{bcd}$ & $17.79 \mathrm{bc}$ & $20.50 \mathrm{bcde}$ & $38.25 \mathrm{ij}$ \\
\hline
\end{tabular}

Keterangan : Angka yang diikuti huruf yang sama menunjukkan tidak berbeda nyata (DMRT 5\%). Media : M0 $\left(\right.$ tanah + kontrol), M1 (Tanah + pupuk kandang $\left.15 \mathrm{t} \mathrm{ha}^{-1}\right)$, M2 (Tanah + fosfat alam $\left.150 \mathrm{~kg} \mathrm{ha}^{-1}\right)$, M3 (Tanah + pupuk kandang $15 \mathrm{t} \mathrm{ha}^{-1}+$ fosfat alam $\left.50 \mathrm{~kg} \mathrm{ha}^{-1}\right)$, M4 (Tanah + pupuk kandang $10 \mathrm{t} \mathrm{ha}^{-1}+$ fosfat alam 100 $\left.\mathrm{kg} \mathrm{ha} \mathrm{a}^{-1}\right)$, M5 (Tanah + pupuk kandang $5 \mathrm{tha}^{-1}+$ fosfat alam $\left.150 \mathrm{~kg} \mathrm{ha}^{-1}\right)$.

\section{Serapan $P$}

Terjadi interaksi antara tanaman inang dan media tanam terhadap nilai serapan P pada 49 hst (Tabel 4). Nilai serapan P yang dihasilkan ini untuk mengetahui aktivitas MA dalam meningkatkan serapan P pada masing-masing jenis tanaman inang dari awal pertumbuhan hingga panen. Spora MA yang berkembang selama proses perbanyakan MA ini melakukan aktivitas dalam mengubah unsur hara $\mathrm{P}$ yang tidak tersedia menjadi $\mathrm{P}$ tersedia dan siap diserap oleh tanaman inang. Perkembangan spora MA dalam perbanyakan MA ini dapat diketahui melalui serapan P nya. Unsur hara P yang diserap tanaman akan digunakan untuk pertumbuhannya dan hasil dari proses fotosintesis berupa karbohidrat digunakan MA saat mengkoloni akar tanaman untuk perkembangannya. Ketika pertumbuhan tanaman itu baik maka perkembangan MA juga akan baik yang dapat diketahui melalui aktivitasnya dalam memperluas serapan hara tanaman. Aktivitas MA dapat menunjukkan peningkatan serapan unsur hara melalui hifa eksternal MA. Hifa eksternal MA dapat 
membantu menyerap unsur hara mencapai zona penipisan hara yang tidak dapat dicapai oleh akar yang tidak terkoloni MA. Diameter hifa eksternal yang sangat kecil dibandingkan dengan akar mampu mempenetrasi pori-pori mikro tanah yang tidak dapat dicapai oleh akar tanaman untuk menyerap unsur hara lebih banyak (Drew et al., 2003).

Tabel 4. Pengaruh perlakuan terhadap serapan P tanaman pada 49 HST.

\begin{tabular}{ccccccc}
\hline \multirow{2}{*}{ Perlakuan } & \multicolumn{7}{c}{ Serapan P $\left(\mathbf{m g}\right.$ tanaman $\left.^{-1}\right)$} \\
\cline { 2 - 7 } & M0 & M1 & M2 & M3 & M4 & M5 \\
\hline Jagung & $46,28 \mathrm{~b}$ & $60,78 \mathrm{bc}$ & $53,98 \mathrm{bc}$ & $57,79 \mathrm{bc}$ & $64,69 \mathrm{bc}$ & $68,03 \mathrm{~cd}$ \\
Kedelai & $3,39 \mathrm{a}$ & $11,36 \mathrm{a}$ & $17,85 \mathrm{a}$ & $10,85 \mathrm{a}$ & $11,00 \mathrm{a}$ & $11,87 \mathrm{a}$ \\
\multirow{2}{*}{ Tithonia } & $54,69 \mathrm{bc}$ & $60,66 \mathrm{bc}$ & $60,40 \mathrm{bc}$ & $68,87 \mathrm{~cd}$ & $84,84 \mathrm{~d}$ & $103,72 \mathrm{e}$ \\
\hline
\end{tabular}

Keterangan : Angka yang diikuti huruf yang sama menunjukkan tidak berbeda nyata (DMRT 5\%). Media : M0 (tanah + kontrol), M1 (Tanah + pupuk kandang $\left.15 \mathrm{t} \mathrm{ha}^{-1}\right)$, M2 (Tanah + fosfat alam $\left.150 \mathrm{~kg} \mathrm{ha}^{-1}\right)$, M3 (Tanah + pupuk kandang $15 \mathrm{t} \mathrm{ha}^{-1}+$ fosfat alam $50 \mathrm{~kg} \mathrm{ha}^{-1}$ ), M4 (Tanah+ pupuk kandang $10 \mathrm{t} \mathrm{ha}^{-1}+$ fosfat alam 100 $\left.\mathrm{kg} \mathrm{ha} \mathrm{a}^{-1}\right)$, M5 (Tanah + pupuk kandang $5 \mathrm{tha}^{-1}+$ fosfat alam $\left.150 \mathrm{~kg} \mathrm{ha}^{-1}\right)$.

\section{pH tanah}

Perlakuan tanaman inang dan media tanam berpengaruh nyata, namun tidak terjadi interaksi antara keduanya terhadap nilai $\mathrm{pH}$ tanah pada 49 hst (Tabel 5)

Tabel 5. Pengaruh perlakuan terhadap $\mathrm{pH}$ tanah.

\begin{tabular}{|c|c|}
\hline Perlakuan & $\mathrm{pH}$ \\
\hline \multicolumn{2}{|l|}{ Tanaman Inang } \\
\hline Jagung & $4,96 \mathrm{a}$ \\
\hline Kedelai & $5,05 \mathrm{~b}$ \\
\hline Tithonia & $4,98 \mathrm{a}$ \\
\hline \multicolumn{2}{|l|}{ Media Tanam } \\
\hline M0 (Kontrol) & $5,08 \mathrm{~b}$ \\
\hline $\begin{array}{l}\text { M1 (Tanah }+ \text { pupuk kandang } 15 \mathrm{t} \\
\text { ha }^{-1} \text { ) }\end{array}$ & $5,00 \mathrm{a}$ \\
\hline $\begin{array}{l}\text { M2 (Tanah + fosfat alam } 150 \mathrm{~kg} \mathrm{ha}^{-} \\
\text {1) }\end{array}$ & $5,00 \mathrm{a}$ \\
\hline $\begin{array}{l}\text { M3 (Tanah + pupuk kandang } 15 \mathrm{t} \\
\left.\mathrm{ha}^{-1}+\text { fosfat alam } 50 \mathrm{~kg} \mathrm{ha}^{-1}\right)\end{array}$ & $4,99 \mathrm{a}$ \\
\hline $\begin{array}{l}\text { M4 (Tanah + pupuk kandang } 10 \mathrm{t} \\
\left.\mathrm{ha}^{-1}+\text { fosfat alam } 100 \mathrm{~kg} \mathrm{ha}^{-1}\right)\end{array}$ & $4,98 \mathrm{a}$ \\
\hline $\begin{array}{l}\text { M5 (Tanah }+ \text { pupuk kandang } 5 \mathrm{t} \mathrm{ha}^{-} \\
\left.1+\text { fosfat alam } 150 \mathrm{~kg} \mathrm{ha}^{-1}\right)\end{array}$ & $4,94 \mathrm{a}$ \\
\hline
\end{tabular}

Keterangan : Angka yang diikuti huruf yang sama pada kolom tanaman inang dan media tanam menunjukkan tidak berbeda nyata (DMRT 5\%).
Reaksi tanah menggambarkan kemasaman atau alkalinitas suatu tanah. Reaksi tanah ini diukur dengan menggunakan skala $\mathrm{pH}$. Skala dengan bacaan antara $0-7$ merupakan $\mathrm{pH}$ masam sedangkan skala dengan bacaan antara $7-14$ merupakan pH basa (Nurhidayati, 2017). Pemberian pupuk kandang dan fosfat alam sebagai media tanam pada tanaman inang dalam kegiatan perbanyakan MA menghasilkan nilai pH antara 4,94 sampai 5,08 sehingga termasuk dalam kategori $\mathrm{pH}$ masam (Tabel 5). Perkembangan spora MA dapat diketahui melalui nilai $\mathrm{pH}$ yang dihasilkan pada media tanam. Aktivitas MA dalam mendekomposisikan bahan organik menghasilkan asam-asam organik dan enzim fosfatase sehingga dapat menurunkan $\mathrm{pH}$ tanah. Enzim fosfatase dapat memacu proses mineralisasi $\mathrm{P}$ organik dengan mengkatalisis pelepasan $\mathrm{P}$ dari kompleks organik sehingga $\mathrm{P}$ menjadi tersedia. Aktivitas MA dalam menghasilkan enzim fosfatase ini yang menyebabkan penurunan $\mathrm{pH}$ tanah (Musafa et al., 2015).

\section{Rasio akar tajuk}

Tanaman inang dan media tanam tidak berpengaruh nyata dalam menghasilkan rasio akar tajuk (Tabel 6). Keberhasilan dalam kegiatan perbanyakan MA dipengaruhi oleh pertumbuhan tanaman inangnya. 
Tabel 6. Pengaruh perlakuan terhadap rasio akar tajuk.

\begin{tabular}{|c|c|}
\hline Perlakuan & $\begin{array}{c}\text { Rasio } \\
\text { akar tajuk }\end{array}$ \\
\hline \multicolumn{2}{|l|}{ Tanaman Inang } \\
\hline Jagung & 0,28 \\
\hline Kedelai & 0,24 \\
\hline Tithonia & 0,32 \\
\hline \multicolumn{2}{|l|}{ Media Tanam } \\
\hline M0 (Kontrol) & 0,49 \\
\hline $\begin{array}{l}\text { M1 (Tanah + pupuk kandang } \\
\left.15 \mathrm{t} \mathrm{ha}^{-1}\right)\end{array}$ & 0,31 \\
\hline $\begin{array}{l}\text { M2 (Tanah + fosfat alam } 150 \\
\left.\mathrm{~kg} \mathrm{ha}^{-1}\right)\end{array}$ & 0.21 \\
\hline $\begin{array}{l}\text { M3 (Tanah + pupuk kandang } \\
15 \mathrm{t} \mathrm{ha}^{-1}+\text { fosfat alam } 50 \mathrm{~kg} \mathrm{ha}^{-1} \text { ) }\end{array}$ & 0,19 \\
\hline $\begin{array}{l}\text { M4 (Tanah + pupuk kandang } \\
10 \mathrm{tha}^{-1}+\text { fosfat alam } 100 \mathrm{~kg} \\
\mathrm{ha}^{-1} \text { ) }\end{array}$ & 0,23 \\
\hline $\begin{array}{l}\text { M5 (Tanah }+ \text { pupuk kandang } 5 \\
\left.\mathrm{t} \mathrm{ha}^{-1}+\text { fosfat alam } 150 \mathrm{~kg} \mathrm{ha}^{-1}\right)\end{array}$ & 0,24 \\
\hline
\end{tabular}

Keterangan : Angka yang diikuti huruf yang sama pada kolom tanaman inang dan media tanam menunjukkan tidak berbeda nyata (DMRT 5\%).

Pertumbuhan tanaman inang yang baik akan mempengaruhi produksi jumlah spora MA yang dihasilkan. Rasio akar tajuk dapat dijadikan sebagai indikasi untuk mengetahui apakah tanaman inang yang digunakan dalam kegiatan perbanyakan MA ini tumbuh dengan baik sehingga produksi spora MA maksimal (Tabel 6). Pertumbuhan tanaman yang baik akan memiliki berat tajuk lebih besar dibandingkan dengan berat akar. Menurut Fisher dan Peter (1996) menjelaskan bahwa beberapa hari pertama pada awal pertumbuhan tanaman, berat kering akar akan melebihi berat kering tajuk. Tetapi, setelah melewati tahap vegetatif tajuk akan bertambah bahan keringnya lebih tinggi daripada berat kering akar dan disaat itu rasio akar tajuk mulai menurun. Rasio akar tajuk akan menurun sampai $<1$ dan terus menurun selama pertumbuhan tanaman hingga 0,25 atau kurang dari itu ketika tanaman dewasa.

\section{Tinggi tanaman inang}

Tidak terjadi interaksi antara tanaman inang dan media tanam pada tinggi tanaman inang. Tanaman inang berpengaruh nyata pada tinggi tanaman berumur 7 hst hingga 49 hst. Sedangkan media tanam tidak berpengaruh nyata pada tinggi tanaman dari 7 sampai 42 hst namun berpengaruh nyata pada 49 hst (Tabel 7). Perkembangan MA sangat dipengaruhi oleh pertumbuhan tanaman inangnya, sehingga pertumbuhan tanaman inang yang baik menjadi tolak ukur keberhasilan dalam kegiatan perbanyakan MA.

Tabel 7. Pengaruh perlakuan terhadap rerata tinggi tanaman.

\begin{tabular}{cccccccc}
\hline Perlakuan & \multicolumn{7}{c}{ Tinggi Tanaman Pada Umur Pengamatan (cm) } \\
\cline { 2 - 8 } & $\mathbf{7 ~ h s t}$ & $\mathbf{1 4}$ hst & $\mathbf{2 1}$ hst & $\mathbf{2 8}$ hst & $\mathbf{3 5}$ hst & 42 hst & 49 hst \\
\hline Tanaman Inang & & & & & & & \\
J & $17,89 \mathrm{a}$ & $28,22 \mathrm{~b}$ & $38,61 \mathrm{~b}$ & $41,67 \mathrm{~b}$ & $48,11 \mathrm{~b}$ & $59,89 \mathrm{c}$ & $72,28 \mathrm{~b}$ \\
K & $16,17 \mathrm{a}$ & $23,89 \mathrm{a}$ & $35,83 \mathrm{~b}$ & $42,67 \mathrm{~b}$ & $48,22 \mathrm{~b}$ & $51,17 \mathrm{~b}$ & $53,61 \mathrm{a}$ \\
T & $23,00 \mathrm{~b}$ & $24,89 \mathrm{a}$ & $30,22 \mathrm{a}$ & $31,89 \mathrm{a}$ & $36,28 \mathrm{a}$ & $43,61 \mathrm{a}$ & $49,17 \mathrm{a}$ \\
\hline Media Tanam & & & & & & & \\
M0 & 18,56 & 25,00 & 34,22 & 37,67 & 42,89 & 49,11 & $54,00 \mathrm{a}$ \\
M1 & 19,44 & 26,00 & 36,33 & 40,22 & 44,78 & 51,67 & $64,11 \mathrm{~b}$ \\
M2 & 19,67 & 27,44 & 38,22 & 42,22 & 47,67 & 52,22 & $63,67 \mathrm{~b}$ \\
M3 & 18,11 & 24,33 & 33,00 & 36,78 & 43,00 & 51,33 & $64,89 \mathrm{~b}$ \\
M4 & 20,78 & 27,22 & 37,22 & 41,00 & 47,78 & 55,00 & $70,11 \mathrm{~b}$ \\
M5 & 17,56 & 24,00 & 30,33 & 34,56 & 39,11 & 50,00 & $65,56 \mathrm{~b}$ \\
\hline
\end{tabular}

Keterangan : Angka yang diikuti huruf yang sama pada kolom tanaman inang dan media tanam menunjukkan tidak berbeda nyata (DMRT 5\%). Tanaman Inang: J Jagung), K (Kedelai), T (Tithonia). Media : M0 (tanah + kontrol), M1 (Tanah + pupuk kandang $15 \mathrm{t} \mathrm{ha}^{-1}$ ), M2 (Tanah + fosfat alam $\left.150 \mathrm{~kg} \mathrm{ha}^{-1}\right)$, M3 (Tanah + pupuk kandang $15 \mathrm{t} \mathrm{ha}^{-1}$ + fosfat alam $\left.50 \mathrm{~kg} \mathrm{ha}-1\right)$, M4 (Tanah + pupuk kandang $10 \mathrm{t} \mathrm{ha}^{-1}+$ fosfat alam $100 \mathrm{~kg} \mathrm{ha}^{-1}$ ), M5 (Tanah + pupuk kandang $5 \mathrm{t} \mathrm{ha}^{-1}+$ fosfat alam $\left.150 \mathrm{~kg} \mathrm{ha}^{-1}\right)$. HST : hari setelah tanam. 
Koloni MA mampu meningkatkan serapan $\mathrm{P}$ untuk pertumbuhan tanaman karena adanya hifa ekternal yang dibentuk oleh MA saat mengkoloni akar. Tanaman inang akan menyediakan karbohidrat untuk MA dan MA akan meningkatkan kemudahan akar tanaman inang dalam menyerap unsur hara $\mathrm{P}$ untuk pertumbuhannya (Tarraf et al, 2017).

\section{Jumlah daun tanaman inang}

Tidak terjadi interaksi antara tanaman inang dan media tanam pada jumlah daun. Tanaman inang berpengaruh nyata pada pengamatan jumlah daun mulai dari 7 hst sampai 49 hst. Berikut hasil jumlah daun yang telah diperoleh (Tabel 8). Pertumbuhan tanaman inang yang baik salah satunya jumlah daun menjadi tolak ukur keberhasilan dalam kegiatan perbanyakan MA.
Sekalipun proses fotosintesis dapat berlangsung pada bagian lain dari tanaman, daun secara umum dipandang sebagai organ produsen fotosintat utama. Pengamatan jumlah daun sangat diperlukan sebagai penunjang untuk menjelaskan proses pertumbuhan yang terjadi. Perbedaan produksi spora MA yang dihasilkan pada jenis tanaman inang ini dikarenakan karakteristik tanaman inang yang bervariasi diantaranya kemampuan beradaptasi pada kondisi pertumbuhan seperti suhu tanah, $\mathrm{pH}$ tanah, kesuburan tanah dan interaksi antara mikroorganisme tanah. Selain itu stabilitas pertumbuhan tanaman inang seperti sistem perakaran dan ukuran akar juga menjadi pertimbangan yang penting dalam produksi spora MA (Tahat et al, 2008).

Tabel 8. Pengaruh perlakuan terhadap rerata jumlah daun.

\begin{tabular}{cccccccc}
\hline Perlakuan & \multicolumn{7}{c}{ Jumlah Daun Pada Umur Pengamatan } \\
\cline { 2 - 8 } & $\mathbf{7}$ hst & $\mathbf{1 4}$ hst & $\mathbf{2 1}$ hst & $\mathbf{2 8} \mathbf{~ h s t}$ & $\mathbf{3 5} \mathbf{~ s t}$ & $\mathbf{4 2} \mathbf{~ h s t}$ & $\mathbf{4 9}$ hst \\
\hline Tanaman Inang & & & & & & & \\
J & $3,22 \mathrm{a}$ & $4,33 \mathrm{a}$ & $3,06 \mathrm{a}$ & $3,22 \mathrm{a}$ & $4,78 \mathrm{a}$ & $6,72 \mathrm{a}$ & $7,61 \mathrm{a}$ \\
K & $3,89 \mathrm{a}$ & $7,89 \mathrm{a}$ & $12,78 \mathrm{~b}$ & $15,28 \mathrm{~b}$ & $18,33 \mathrm{~b}$ & $19,89 \mathrm{~b}$ & $21,44 \mathrm{~b}$ \\
T & $24,28 \mathrm{~b}$ & $28,67 \mathrm{~b}$ & $23,67 \mathrm{c}$ & $24,78 \mathrm{c}$ & $33,56 \mathrm{c}$ & $39,17 \mathrm{c}$ & $48,94 \mathrm{c}$ \\
\hline Media Tanam & & & & & & & \\
M0 & 11,22 & 13,44 & 13,00 & 14,00 & 17,67 & 20,56 & 23,33 \\
M1 & 10,22 & 12,44 & 13,44 & 14,11 & 19,89 & 21,67 & 25,11 \\
M2 & 10,44 & 14,56 & 13,11 & 14,22 & 18,00 & 22,89 & 28,78 \\
M3 & 10,33 & 13,56 & 13,22 & 14,67 & 19,67 & 21,56 & 26,44 \\
M4 & 10,11 & 13,22 & 14,22 & 14,89 & 19,00 & 22,67 & 26,78 \\
M5 & 10,44 & 14,56 & 12,00 & 14,67 & 19,11 & 22,22 & 25,56 \\
\hline
\end{tabular}

Keterangan : Angka yang diikuti huruf yang sama pada kolom tanaman inang dan media tanam menunjukkan tidak berbeda nyata (DMRT 5\%). Tanaman Inang: J (Jagung), K (Kedelai), T (Tithonia). Media : M0 (tanah + kontrol), M1 (Tanah + pupuk kandang $15 \mathrm{tha}-1)$, M2 (Tanah + fosfat alam $150 \mathrm{~kg}$ ha-1), M3 (Tanah + pupuk kandang $15 \mathrm{t}$ ha-1 + fosfat alam $50 \mathrm{~kg}$ ha-1), M4 (Tanah + pupuk kandang $10 \mathrm{t} \mathrm{ha-1}+$ fosfat alam $100 \mathrm{~kg}$ ha1), M5 (Tanah + pupuk kandang 5 t ha-1 + fosfat alam $150 \mathrm{~kg}$ ha-1). hst : hari setelah tanam

\section{Hubungan koloni ma dengan jumlah spora MA}

Peningkatan persentase koloni MA yang dihasilkan pada masing-masing jenis tanaman inang secara signifikan mampu meningkatkan jumlah spora MA. Persentase koloni MA antara $33-60 \%$ pada tanaman inang menghasilkan jumlah spora MA sebesar 280 - 325 spora. Hubungan yang signifikan antara koloni MA dalam meningkatkan jumlah spora MA dikarenakan nilai $\mathrm{r}$ yang dihasilkan pada uji korelasi berturut-turut 0,$77 ; 0,92 ; 0,73$ lebih besar dari 0,27 ( $\mathrm{r}$ tabel $5 \%$ ). Besarrnya pengaruh koloni MA dalam meningkatkan jumlah spora MA diketahui melalui uji regresi linier sederhana pada masing-masing jenis tanaman inang yang menunjukkan koefisien determinasi $\left(\mathrm{R}^{2}\right)$ berturut turut 0,$68 ; 0,92 ;$ dan 0,54 . Melalui nilai $\mathrm{R}^{2}$ dapat diketahui $68 \%, 92 \%, 54 \%$ jumlah spora MA yang dihasilkan dari masing-masing 
jenis tanaman inang dipengaruhi oleh koloni MA dan $32 \%, 8 \%, 46 \%$ lainnya dipengaruhi oleh faktor lain (Gambar 1). Semakin meningkat koloni MA pada taraf tertentu akan memberi peluang yang besar untuk meningkatkan jumlah spora MA. Jenis tanaman inang yang digunakan mempengaruhi peningkatan koloni MA pada akar dan nantinya tanaman inang tersebut memiliki peran dalam meningkatkan produksi spora MA. Menurut Widiastuti et al. (2005) tingginya tingkat koloni MA menunjukkan kemampuan beradaptasi yang tinggi dari spora MA terhadap tanaman inangnya. Kesesuaian tanaman inang dengan spora MA akan menyebabkan spora MA mengkoloni akar dengan baik serta menyebar luas ke jaringan akar tanaman dan selanjutnya meningkatkan jumlah spora MA yang dihasilkan.
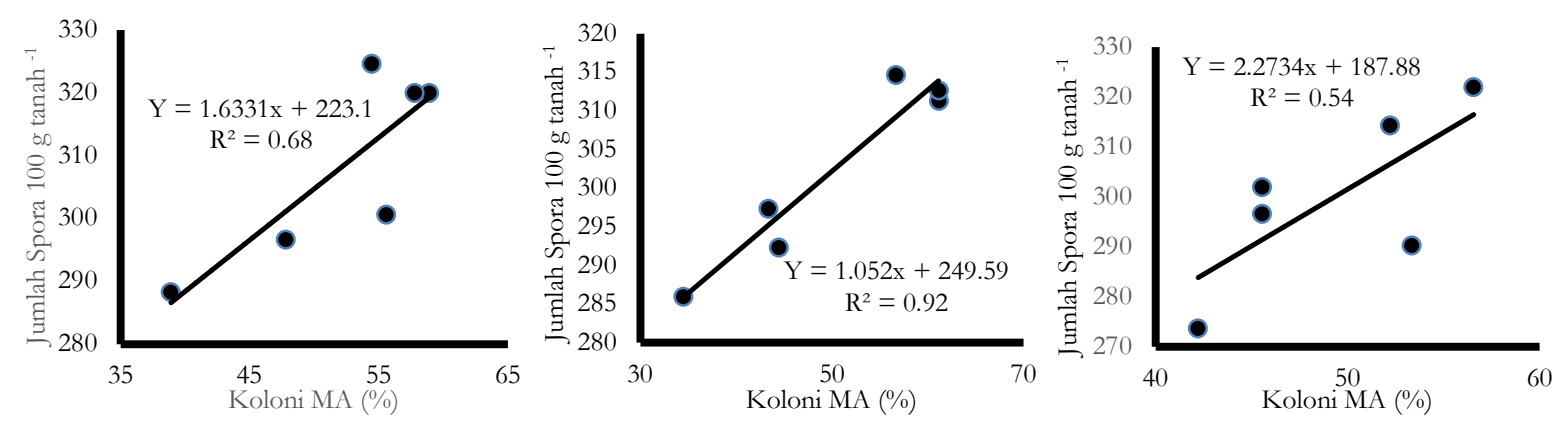

Gambar 1. Hubungan koloni MA dengan jumlah spora MA pada akar tanaman inang (a) jagung, (b) kedelai, dan (c) tithonia

\section{Hubungan koloni MA dengan serapan P}

Peningkatan persentase koloni MA yang dihasilkan pada masing-masing jenis tanaman inang secara signifikan mampu meningkatkan serapan P tanaman. Persentase awal koloni MA sebesar 35-45 \% mampu meningkatkan serapan P. Selanjutnya penyerapan P mengalami masa stagnan pada persentase koloni MA $45-55 \%$, hal ini dikarenakan MA hanya mengkoloni akar namun belum meningkatkan jalinan hifa sehingga hifa eksternal yang telah terbentuk sebelumnya tidak menyebar secara luas pada area perakaran dan penyerapan $\mathrm{P}$ tidak mengalami peningkatan. Seiring dengan meningkatnya koloni MA, pada persentase 55 $65 \%$ hifa eksternal mulai mengalami peningkatan dan menyebar luas pada area perakaran sehingga serapan $\mathrm{P}$ juga akan meningkat. Hubungan yang signifikan antara koloni MA dalam meningkatkan serapan $\mathrm{P}$ dikarenakan nilai $\mathrm{r}$ yang dihasilkan pada uji korelasi berturut-turut 0,$69 ; 0,77 ; 0,77$ lebih besar dari 0,27 ( $\mathrm{r}$ tabel $5 \%$ ). Besarrnya pengaruh koloni MA dalam meningkatkan serapan P diketahui melalui uji polynomial orthogonal dan persamaan yang dihasilkan dari uji polinomial orthogonal adalah respon kubik. Tanaman jagung menunjukkan persamaan yang diperoleh yaitu $\mathrm{Y}$ $=0,0074 \mathrm{x}^{3}-1,0565 \mathrm{x}^{2}+50,606 \mathrm{x}-759,03$ dan $\mathrm{R}^{2}=0,99$, tanaman kedelai menunjukkan persamaan yang diperoleh yaitu $\mathrm{Y}=0,0033 \mathrm{x}^{3}-$ $0,4806 x^{2}+23,281 x-362,52$ dan $R^{2}=0,83$, selanjutnya tanaman tithonia menunjukkan persamaan yang diperoleh yaitu $\mathrm{Y}=0,0607 \mathrm{x}^{3}-$ $8,7923 x^{2}+424,31 x-6758,2$ dan $R^{2}=0,74$. Melalui nilai $\mathrm{R}^{2}$ dapat diketahui $99 \%, 83 \%, 74$ $\%$ jumlah spora MA yang dihasilkan dari masing-masing jenis tanaman inang dipengaruhi oleh koloni MA dan 1\%, $17 \%$, 26\% lainnya dipengaruhi oleh faktor lain (Gambar 2). Fungsi MA erat kaitannya dengan ketersediaan $P$. Peningkatan serapan $\mathrm{P}$ oleh tanaman yang terkoloni MA sebagian besar karena MA membentuk hifa eksternal yang berfungsi sebagai sistem perakaran dan mampu menyediakan permukaan akar yang lebih efektif untuk menyerap unsur hara. Menurut Zuhry dan Puspita (2008), meningkatnya koloni MA pada akar mampu memproduksi jalinan hifa ekternal secara intensif yang nantinya mampu meningkatkan kapasitas penyerapan unsur hara. Semakin tinggi koloni MA pada akar maka semakin tinggi serapan haranya. Adanya hubungan antara spora MA dan tanaman inang memiliki keuntungan dalam menyerap unsur $\mathrm{P}$ 
melebihi batas penipisan hara pada area perakaran. Akar yang terkoloni oleh MA sangat efisien dalam memperoleh unsur $\mathrm{P}$ dibandingkan dengan akar tanpa koloni MA.
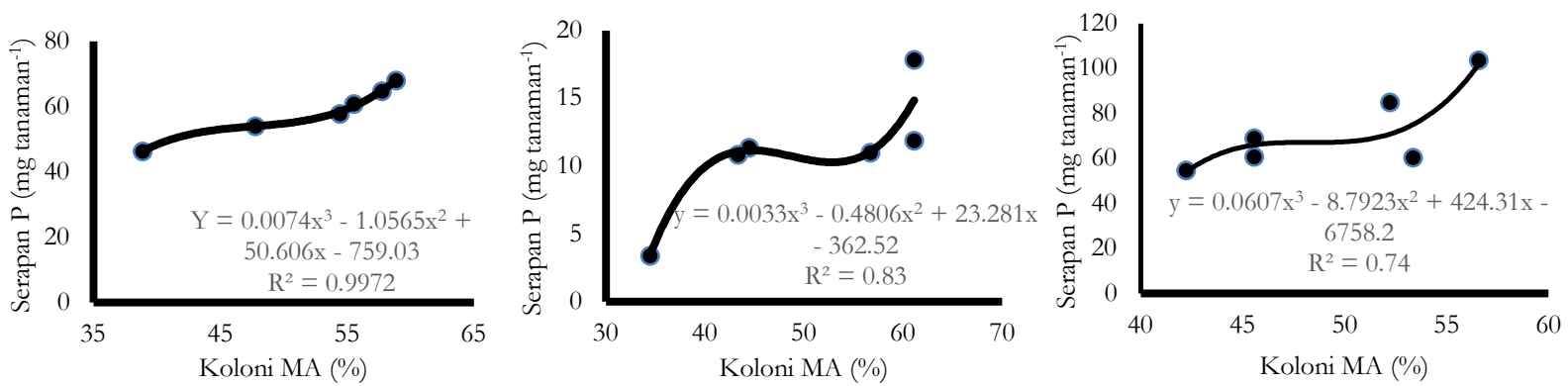

Gambar 2. Hubungan koloni MA dengan serapan P pada tanaman inang (a) jagung, (b) kedelai dan (c) tithonia

\section{Hubungan antara $\mathrm{pH}$ tanah dengan jumlah spora $M A$}

Penurunan $\mathrm{pH}$ tanah yang dihasilkan pada masing-masing jenis tanaman inang secara signifikan mampu meningkatkan jumlah spora MA. Tanaman jagung menghasilkan $\mathrm{pH}$ lebih rendah sebesar 4,96 dibandingkan dengan tanaman kedelai dan tithonia serta menghasilkan jumlah spora MA tertinggi sebesar 325 spora (Tabel 5). Hubungan yang signifikan antara penurunan $\mathrm{pH}$ tanah dalam meningkatkan jumlah spora MA dikarenakan nilai $r$ yang dihasilkan pada uji korelasi berturut-turut 0,70 ; 0,59; 0,63 lebih besar dari 0,27 ( $\mathrm{r}$ tabel $5 \%$ ). Besarrnya pengaruh $\mathrm{pH}$ tanah dalam meningkatkan jumlah spora MA diketahui melalui uji regresi linier sederhana pada masing-masing jenis tanaman inang yang menunjukkan koefisien determinasi $\left(\mathrm{R}^{2}\right)$ berturut turut 0,64; 0,39; dan 0,45. Melalui nilai $\mathrm{R}^{2}$ dapat diketahui $64 \%, 39 \%$, $45 \%$ jumlah spora MA yang dihasilkan dari masing-masing jenis tanaman inang dipengaruhi oleh $\mathrm{pH}$ tanah dan $36 \%, 61 \%, 55 \%$ lainnya dipengaruhi oleh faktor lain (Gambar 3).
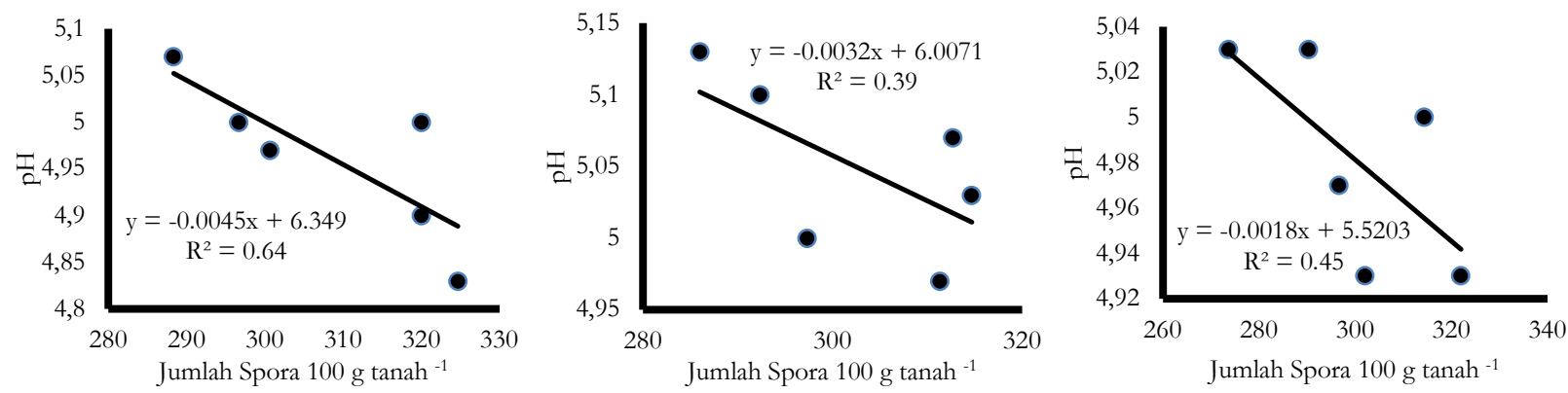

Gambar 3. Hubungan pH tanah dengan jumlah spora MA (a) jagung, (b) kedelai, (c) tithonia

Penelitian Hermawan et al. (2015) terkait perkembangan MA berdasarkan tingkat kedalaman gambut menunjukkan pada kedalaman 0-60 cm jumlah spora MA genus Glomus sp yang dihasilkan sebesar 398 - 495 spora $100 \mathrm{~g}$ tanah- $^{-1}$. Hal ini dikarenakan semakin dalam tanah gambut kondisi $\mathrm{pH}$ tanah nya semakin masam, pada kedalaman $60 \mathrm{~cm} \mathrm{pH}$ tanah yang dihasilkan sebesar 4,5. Kondisi $\mathrm{pH}$ tanah masam akan mampu dimanfaatkan oleh 


\section{Jurnal Tanah dan Sumberdaya Lahan Vol 7 No 1 : 109-119, 2020 e-ISSN:2549-9793, doi: 10.21776/ub.jts1.2020.007.1.14}

MA dalam beradaptasi dengan lingkungan tersebut dan memungkinkan spora akan semakin banyak berkembang dikarenakan MA memiliki sifat arcidophylis (senang dengan kondisi yang asam). Hal ini sesuai dengan pernyataan Smith dan Read (2008) bahwa $\mathrm{pH}$ tanah relatif masam menyebabkan unsur hara terutama fosfor akan diikat (difiksasi). Kondisi yang ini MA dapat membantu tanaman untuk menyerap unsur hara tersebut. Beberapa tanaman akan mengalami kesulitan dalam proses pertumbuhan dan menyerap beberapa unsur hara. Sebagai salah satu solusinya tanaman tersebut akan lebih meningkatkan simbiosisnya terhadap MA untuk membantu dalam penyerapan unsur hara. MA memiliki kecenderungan untuk membentuk spora lebih banyak pada kondisi yang tertekan.

\section{Kesimpulan}

Terdapat interaksi antara tanaman inang dan media tanam dalam menghasilkan jumlah spora MA dan koloni MA. Media tanam M5 (fosfat alam $150 \mathrm{~kg} \mathrm{ha}^{-1}+$ pupuk kandang $5 \mathrm{tha}^{-1}$ ) pada tanaman jagung menjadi media tanam paling baik dalam kegiatan perbanyakan MA ini dengan jumlah spora MA tertinggi sebesar 324,67 spora. Media tanam M5 (fosfat alam $150 \mathrm{~kg} \mathrm{ha}^{-1}+$ pupuk kandang $5 \mathrm{t} \mathrm{ha}^{-1}$ ) pada tanaman kedelai menjadi media tanam paling baik untuk perbanyakan MA ini dengan koloni MA tertinggi sebesar $61,11 \%$.

\section{Daftar Pustaka}

Carrenho, R., Trufem, S.F.B. and Bononi, V.L.R. 2002. Effects of using different host plants on the detected biodiversity of arbuscular mycorrhiza fungi from an agroecosystem. Revista Brasileira de Botânica 25 (1): 93 - 101.

Drew, E.A., Murray, R.S. and Smith, S.E. 2003. Beyond the rhizosphere: growth and function of arbuscular mycorrhizal external hyhae in sands of varying pore size. Plant, Cell \& Environment 251: $105-114$

Fisher, N.M. dan Peter, G. 1992. Fisiologi Tanaman Budidaya Tropik. Gajah Mada University Press. Yogyakarta. p 250-257

Hanafiah, A.S., Sabrina, T. dan Guchi, H. 2009. Biologi dan Ekologi Tanah. Universitas Sumatera Utara. Medan.

Hermawan, H., Muin, A. dan Wulandari, R.S. 2015. Kelimpahan fungi mikoriza arbuskula (FMA) pada tegakan ekaliptus (Eucalyptus pellita) berdasarkan tingkat kedalaman di lahan gambut. Jurnal Hutan Lestari 3(1) : 124 - 132.

Herryawan, K.M. 2012. Perbanyakan inokulum fungi mikoriza arbuskula (FMA) secara sederhana. Pastura 2 (2) : $57-60$.

Musafa, M.K., Aini, L.Q. dan Prasetya, B. 2015. Peran mikoriza arbuskula dan bakteri Pseudomonas fluorescens dalam meningkatkan serapan $\mathrm{P}$ dan pertumbuhan tanaman jagung pada Andisol. Jurnal Tanah dan Sumberdaya Lahan 2 (2): 191 197.

Nurbaity, A. dan Prafitiasari, M. 2010. Infektivitas inokulan Glomus sp. dan Gigaspora sp. pada berbagai komposisi media zeolit-arang sekam dan pengaruhnya terhadap pertumbuhan sorghum (Sorghum bicolor). Jurnal Agrikultura 21 (1) : 39 45.

Nurhidayati. 2017. Kesuburan dan Kesehatan Tanah. Intimedia. Malang. p 78

Rosliani, R., Hilman, Y. dan Sumarni, N. 2009. Pemanfaatan mikoriza, bahan organik, dan fosfat alam terhadap hasil, serapan hara tanaman mentimun, dan sifat kimia pada tanah masam Ultisol. Jurnal Hortikultura 19(1) : 66 - 74.

Singh, H. and Reddy, M.S. 2011. Effect of inoculation with phosphate solubilizing fungus on growth and nutrient uptake of wheat and maize plants fertilized with rock phosphate in alkaline soils. European Journal of Soil Biology 47 (1) : $30-34$.

Smith, S.E and Read, D.J. 2008. Mychorrhizal Symbiosis. Third Edition. Academic Press. Harcourt Brace And Company Publishers, San Diego. p 91

Syibli, M.A., Muhibbudin, A. and S. Djauhari, S. 2013. Arbuscular mycorrhiza fungi as as indicator of soil fertillity. Agrivita 35 (1) : 44-53.

Tahat, M.M., Kamaruzaman, S., Radziah, O., Kadir, J. and Masdek, H.N. 2008. plant host selectivity for multiplication of Glomus mosseae spore. International Journal of Botany 4(4) : 466- 470.

Tarraf, W., Ruta, C., Tagarelli, A., Cillis, F.D. and Mastro, G.D. 2017. Influence of arbuscular mycorrhizae on plant growth, essential oilproduction and phosphorus uptake of Salvia officinalis L. Industrial Crops and Products 102 (1) : 144-153.

Widiastuti, H., Sukarno, N., Darusman, Latifah, dan Kosim. 2005. Tingkat kedinian infeksi Acaulospora tuberculata dan Gigaspora margarita pada bibit ketapa sawit. Jurnal Mikrobiologi Indonesia. 42-44.

Zuhry, E. dan Puspita, F. 2008. Pemberian cendawan mikoriza arbuskular (CMA) pada tanah podzolik merah kuning (PMK) terhadap pertumbuhan dan produksi kedelai (Glycine max (L) Merill). SAGU. $7: 25-29$. 
halaman ini sengaja dikosongkan 